\title{
Effect of climatic and non-climatic factors on fishing activities in Lake Victoria, Kisumu County, Kenya
}

\author{
APINDI JANE AKOTH, ISHMAIL O. MAHIRI ${ }^{\boldsymbol{\eta}}$, KENNEDY OBIERO \\ Department of Geography, Kenyatta University. Mfangano Island, Kakamega Centre, Suba North, Kenya. `email: mahiri.ishmail@ku.ac.ke
}

Manuscript received: 4 March 2021. Revision accepted: 12 June 2021.

\begin{abstract}
Akoth AJ, Mahiri OS, Obiero K. 2021. Influence of climatic and non-climatic factors on fishing activities in Lake Victoria, Kisumu County, Kenya. Intl J Bonorowo Wetlands 11: 7-17. This study aimed to determine the impact of climatic factors like dry spells, rainfall, wind strength, and non-climatic factors like overfishing, water hyacinth, and predators on fishing activities on the shores of Lake Victoria in Kisumu County. The research used a descriptive survey design. The study area comprised thirty-two beaches, of which eight were chosen to represent Kisumu County as a whole. The eight beaches were sampled using a systematic sampling technique. The data was collected using a sample size of 362 respondents. Over the past ten years, fish landing data was collected at the beaches and the Kenya Marine and Fisheries Research Institute (KEMFRI), while climate data was received from the Kisumu Airport Regional Meteorological Department. Primary data was collected from the beaches using questionnaires and interviews, whereas secondary data was collected from KEMFRI using document analysis guidance, books, and publications. The results were processed and analyzed with the help of the Statistical Package for Social Sciences (SPSS) application, which assisted in the calculation of frequencies, means, and percentages. The study discovered a linkage between climatic factors and fishing activity. According to the study, climatic factors and fishing activities have a substantial relationship. The amount of rainfall affected fish captures, albeit the effect differed by fish species; Oreochromis ( $\mathrm{r}=.260)$, Lates niloticus $(\mathrm{r}=130)$, and Protopterus $(\mathrm{r}=.184)$ had positive correlations with rainfall, whereas Rastrinoebola argentea and Claras gariepinus had negative correlations. Overall, the findings showed a positive correlation coefficient ( $\mathrm{r}=.079)$ between rain and total fish catch. Fish numbers in the lake have decreased due to a dry season accompanied by high temperatures. A strong wind had a negative impact on fishing activities, whereas mild to moderate wind favored fish catch. Nonclimatic factors had a significant detrimental effect on fishing activity in Lake Victoria, according to the study. The researcher came to the following conclusions based on the findings: there was a relationship between climatic elements and fishing activities; non-climatic factors primarily influenced fishing activities negatively; however, fishers implemented mitigation strategies to help address nonclimatic factors. Policymakers should regulate fish harvesting as dictated by climatic and weather variations, assess the impact of nonclimatic elements in fish production, and recommend appropriate mitigation measures. Finally, regulations should be enhanced to save endangered fish species from extinction, according to the findings.
\end{abstract}

Keywords: Climatic elements, fishing, Kisumu, Lake Victoria, non-climatic factors

\section{INTRODUCTION}

Fishing is one of the oldest activities of civilization, and it is practiced for both sustenance and commercial purposes throughout the world. It is highly commercialized in developed countries while primarily carried out for subsistence in developing countries. Fishing occurs along the coast, in sheltered seas, and inland freshwaters (Kimathi et al., 2013). The primary fishing grounds of the world, on the other hand, are found in the chilly waters of the Pacific and Atlantic coasts in the northern hemisphere's temperate latitudes. Each contributes $40 \%$ of global yearly fish catches, with the Indian Ocean accounting for roughly $4 \%$ and aquaculture accounting for about $15 \%$. (AlooObudho 2010). In many regions of the world, fish has been a significant element of people's diets since time immemorial. Because of advances in technology, such as more powerful engines and advanced equipment, fish catches have increased dramatically during the last century.

Although fishery resources are renewable, they can also be depleted depending on how they are utilized, or an optimal benefit cannot be realized due to the industry's numerous problems. In the realm of fisheries, decline and variety in fish catch are a fact of life. Many climatic and non-climatic factors can have an impact on fishing activities. For example, the Intergovernmental Panel on Climate Change (IPCC) (2001), as reported by Muthama et al. (2007), stated that oscillations in fish abundance are increasingly being viewed as biological reactions to medium-term climatic variations, as well as overfishing and other anthropogenic influences.

Lake Victoria, the world's second-biggest freshwater lake by surface area $\left(68,800 \mathrm{~km}^{2}\right)$, houses a large community of fishermen who rely on the lake for their livelihood (Karsin 2001). Tanzania, Kenya, and Uganda share the lake's borders. It is $1,134 \mathrm{~m}$ asl., has a volume of $2,760 \mathrm{~km}^{3}$, and average and maximum depths of 40 and 80 meters, respectively (Andjelic, 1999). The threat to Lake Victoria's biodiversity continues to grow, with fisheries being the most visible example. Ochieng (2012) studied the Lake Victoria aquatic system for nearly ten years and discovered that a significant section of the cichlid fauna formerly thought extinct is still alive. He also found that Lake Victoria's Nile perch standing stocks declined while 
the small pelagics increased. Overfishing, illicit fishing gear, and environmental degradation in the catchment areas contribute to the loss of Nile perch. Because of nutrient levels, different parts of the lake produce varied amounts of fish. Clarias gariepianus, Protopterus aethiopicus, Ovechromis spp., and haplochromines spp. have all boosted their captures due to the growth of water hyacinth The herb provides a safe haven, nesting grounds, and food sources (Njiru et al., 2012). Higher construction along the coastline combined with increased rainfall can generate run-off, alter water flows, and cause sedimentation in coastal waters, according to a report released by the Wildlife Conservation Society (WCS) on August 12th, 2011 (WCS 2011). Unsustainable levels of fishing and the effects of global climate change, according to the report, are the greatest dangers to the country's marine ecosystems, both of which have wreaked havoc on the Indian Ocean coral reefs. Inland fishing grounds in Kenya, such as Lakes Turkana, Naivasha, Victoria, and significant rivers like the Tana and Nzoia, are witnessing fish population declines due to climate change and other factors (Ochieng 2012).

Earlier studies have found that climatic and nonclimatic factors impact fishing operations in the areas where they were conducted (LVEMP 2011; Okonga 2010); this has yet to be proven in Kisumu County. As a result, this research aimed to identify the relationship between climatic factors and fishing activities, specifically regarding the different types of fish caught and the number of fish caught throughout the rainy and dry seasons. It also looked at how non-climatic factors affected the volume and variety of fish captured.

The objective of this study was to (i) to determine the relationship between climatic elements and fishing activities, (ii) to determine the relationship between nonclimatic factors and fishing activities, (iii) to examine fishers' mitigation measures for dealing with the influence of climatic elements and non-climatic factors on fishing activities.

\section{MATERIALS AND METHODS}

\section{Research design}

The descriptive survey research design was utilized in this study to acquire information from the sample population on the impact of climate variability on fish production using both quantitative and qualitative methodologies. According to (Muganda 2010), the purpose of a descriptive study is to provide the researcher with a profile or to describe relevant features of the phenomena of interest from an individual, organization, industry, or another perspective. The descriptive survey design was adopted for this study because it allowed the researcher to describe elements that influence fishing activity in Lake Victoria in great detail.

\section{Study area}

This research was carried out on the beaches of Kisumu County, Kenya, which are located along the Lake Victoria shoreline (Figure 1). Kisumu County is located in the Lake area. It is bordered on the south by Lake Victoria, on the north by Siaya County, Vihiga County, and Nandi County. On the northeast by Kericho County and the south by Homa-Bay County. With a surface area of 69,000 square kilometers, Lake Victoria is the world's second-largest lake. Tanzania holds $49 \%$ of the lake's area, Uganda $45 \%$, and Kenya 6\%. Lake Victoria dominates Kenya's fishing sector. It accounted for $94 \%$ of the entire catch of 193,789 tonnes of fish in 1995, while marine fishing accounted for 3\%. (Omwenga et al. 2004).
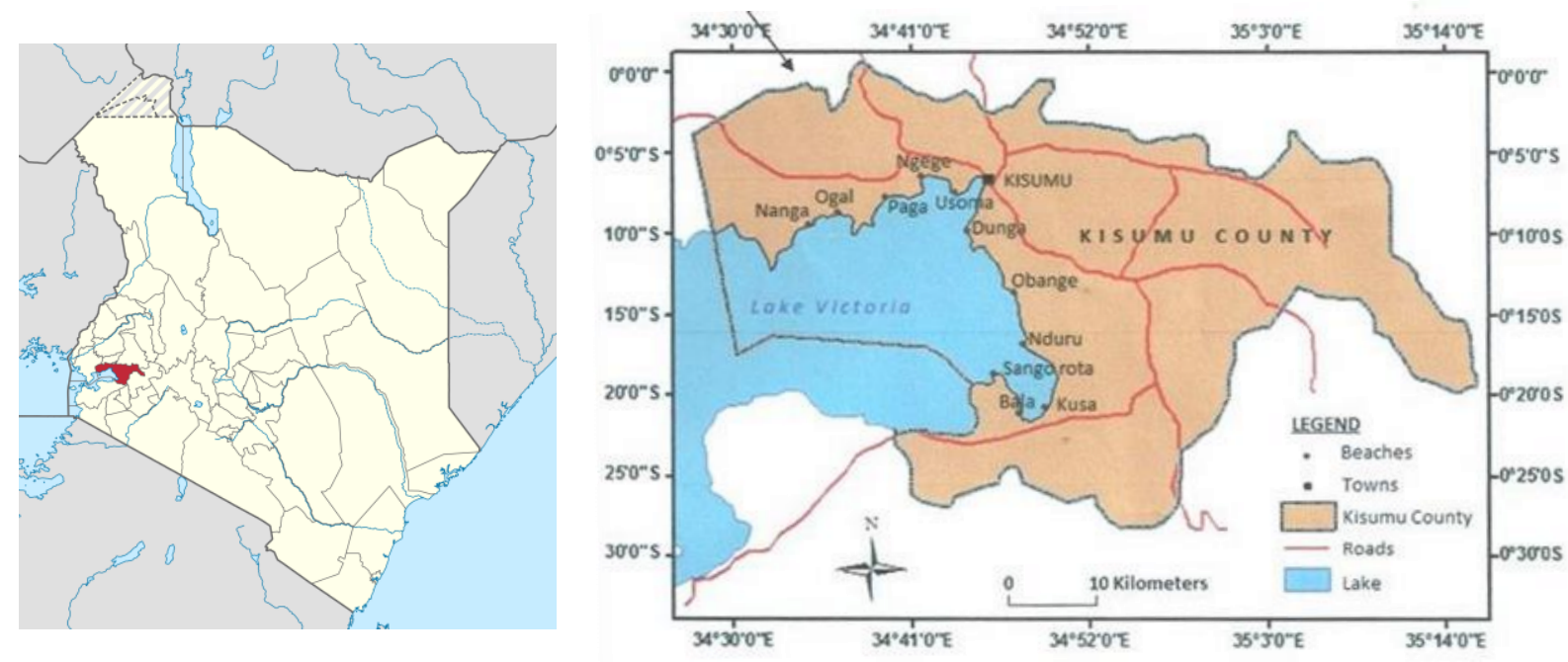

Figure 1. Some beaches along the shoreline of Lake Victoria, Kisumu County, Kenya 
Kisumu County is located between latitudes $00^{\circ} 00,{ }^{\text {,e }}$ and $00^{0} 30^{\circ e} \mathrm{~S}$ and longitudes $34^{\circ} 28^{\mathrm{ee}} \mathrm{E}$ and $35^{\circ} 15^{\mathrm{ee}} \mathrm{E}$. Kisumu County has a total area of $2,085 \mathrm{~km}^{2}, 20 \%$ of which is covered by water, primarily Lake Victoria. The research was carried out on the beaches of Kisumu County, which run along the shore of Lake Victoria. Kisumu County is divided into six districts. However, the shoreline only stretches over three of them: Kisumu West, Kisumu East, and Nyando. In these three districts, there are thirtytwo beaches. In Table 1, the names of the beaches are listed.

\section{Climate}

Kisumu County enjoys various climate conditions between Lake Victoria's north and south coasts (GoK 2008a, 2008b, and 2008c). The northern side, which includes both the Kisumu East and Kisumu West districts, has an average yearly temperature of $20^{\circ} \mathrm{C}$ to $35^{\circ} \mathrm{C}$ degrees Celsius. The annual rainfall pattern in the County (Figure 2) is bimodal, with long rains falling between March and May and short rains falling between September and November. As documented at the Maseno Agricultural Training Centre, some locations endowed with hills, such as Maseno Division and Muhoroni, receive considerable rainfall ranging between $1500 \mathrm{~mm}$ and $1800 \mathrm{~mm}$ yearly (GoK 2008a) (ATC). Low-altitude areas, such as the Kano lowlands and Kombewa Division, receive less yearly rainfall, ranging from 600 to $1280 \mathrm{~mm}$.

\section{Socio-economic activities}

Kisumu County's socio-economic activities are influenced by various circumstances, including rainfall consistency and closeness to Lake Victoria (GoK 2008a, 2008b, and 2008c). Fishing is the primary source of income for people who live on Lake Victoria's shoreline, while agriculture is the primary source of income for those who live further away. Restrineobola argentea, Oreochromis spp., Lates niloticus, Protoptrerus spp., Clarias gariepinus, Haplochromine spp., and Synodontis spp. are economically exploited fish species in Lake Victoria, Kisumu County, according to Omoro (2011). According to him, sugarcane is the principal cash crop farmed in Kisumu County, especially in Muhoroni, Miwani, Kibos, and sections of Nyando District. Rice is another cash crop cultivated along the Nyando and Awach rivers banks near Miwani and lower Nyakach, respectively. The County is home to the Ahero and West Kano irrigation schemes used for rice cultivation.

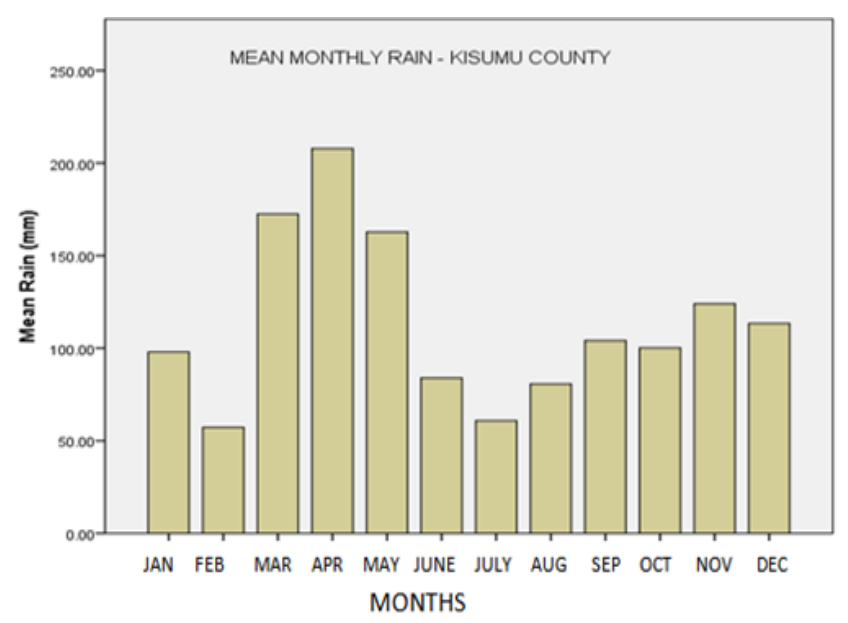

Figure 2. Mean monthly rainfall distribution over Lake Victoria, Kisumu County (2009- 2011). Source: Kenya Meteorological Department-Kisumu Airport (2014).

Table 1. Beach Management Units in Kisumu County, Kenya

\begin{tabular}{|c|c|c|c|c|c|c|}
\hline $\begin{array}{c}\text { Kisumu } \\
\text { West }\end{array}$ & $\begin{array}{c}\text { Population } \\
\text { of fishermen }\end{array}$ & $\begin{array}{c}\text { Kisumu } \\
\text { East }\end{array}$ & $\begin{array}{c}\text { Population } \\
\text { of fishermen }\end{array}$ & $\begin{array}{l}\text { Nyando } \\
\text { District } \\
\end{array}$ & $\begin{array}{c}\text { Population } \\
\text { of fishermen }\end{array}$ & $\begin{array}{c}\text { Total } \\
\text { Population } \\
\end{array}$ \\
\hline Asat & 183 & Paga & 173 & Singida & 109 & \\
\hline Arongo & 70 & Usoma & 76 & Kusa & 230 & \\
\hline Nanga & 155 & Nyandiwa & 52 & Kombewa & 230 & \\
\hline Kihanja & 55 & Oseth/Obange & 126 & Bala & 120 & \\
\hline Nyamarwaka & 149 & Kaloleni & 61 & Sangorota & 270 & \\
\hline Kobudho & 123 & Rare & 201 & Koguta & 220 & \\
\hline Kagwel & 36 & Ugwe & 55 & & & \\
\hline Othany & 98 & Ochok & 68 & & & \\
\hline Kaloka & 91 & Ongenya & 84 & & & \\
\hline \multirow[t]{7}{*}{ Bao } & 252 & Usare & 141 & & & \\
\hline & & Nduru & 86 & & & \\
\hline & & Ogal & 60 & & & \\
\hline & & Ngege & 83 & & & \\
\hline & & Dunga & 393 & & & \\
\hline & & Kichinjio & 233 & & & \\
\hline & & Mawembe & 110 & & & \\
\hline Total & 1,212 & & 2,002 & & 1,179 & 4,393 \\
\hline
\end{tabular}


Food crops such as maize, beans, sorghum, cowpeas, and fruits have great promise in high-altitude locations like Maseno, Muhoroni, and Upper Nyakach, which receive consistent rainfall. In the high-altitude areas of Koru, Muhoroni, and Maseno, livestock rearing is done, particularly dairy cattle. Other economic activities like trade and industry predominate in the county's metropolitan centers. Sugar factories in Kibos, Chemelil, and Muhoroni and rice milling in Ahero and Kibos are among them (Okonga 2010).

\section{Target population}

This research focused on all 32 landing beaches along Lake Victoria's shoreline in Kisumu County. Ten of the 32 beaches are in the Kisumu West District, 16 in the Kisumu East District, and six in the Nyando District. A total of 4,393 registered fishers make up the target population (Table 1). This is based on the GOK District Development Plans (2008).

\section{Sampling technique and sample size}

According to Cohen and Manion (2006), A study of social science nature requires the selection of at least a quarter of the sampling units. Because this is a social scientific study, 8 beaches were sampled using a systematic sampling technique, accounting for $25 \%$ of the 32 beaches in Kisumu County on Lake Victoria. Table 2 demonstrates how Cohen and Manion's 25\% rule was used to estimate the sample size (2006). Kisumu County was chosen from neighboring counties around the Lake Victoria shoreline using a purposive sample strategy. The most appropriate sampling technique utilized to determine the visited beaches was systematic random sampling due to the minimal landing beaches. Furthermore, the researcher provided all of the beaches that took part in the study an equal opportunity. The 8 beaches were identified by selecting every 4th beach in Kisumu West District, then Kisumu East, and finally Nyando District, starting with the first one listed alphabetically in Kisumu West District. According to Kombo and Tromp, this procedure was fair because it was not biased (2006). A sample size of 354 fishers and 8 beach managers from the sampled beaches were utilized as respondents to acquire data from the study region, representing $25 \%$ of the total population of the examined 8 beaches. As a result, there were 354 responders in the research region (Table 2).

\section{Data collection}

Questionnaires were distributed to the sampled respondents in the 8 selected beaches within Kisumu County to obtain primary data.

\section{Questionnaire}

According to Orodho (2012), A questionnaire is used to acquire information and viewpoints about a phenomenon from knowledgeable persons about the subject. Questionnaires are by far the most widely utilized data collection tool. A questionnaire was used to collect data from both teachers and students in this study. According to Musungu and Nasongo, the questionnaire was an appropriate form of data acquisition because it allowed the researcher to reach many people in a short amount of time (2008). It also ensured secrecy, allowing for more candid and objective data to be acquired. Questionnaires were utilized to collect primary data from fishers, including fish species and daily catch amounts, the impact of climatic and non-climatic conditions on fish activities, and potential mitigation methods. Two portions were divided into the questionnaires. The first half comprised questions about the background of fishers, while the second portion contained questions concerning beach fishing practices. The return rate for fishers' questionnaires was $84.2 \%$ (298 fishers).

\section{Interview guide}

According to Keith (2006), An interview schedule is a guide that an interviewer adopts when conducting a structured interview. It consists of two parts: a list of questions that must be answered precisely as written and guidelines for the interviewer on how to answer the questions. The questions are listed in the order that they will be asked. The questions are constructed to be administered literally, word by word. Not only must the questions express what information is being requested of respondents, but they must also indicate the form or manner in which respondents are to respond to the questions. Interviews are used to follow up on questionnaire results in depth with smaller samples, according to Orodho (2008). The researcher interviewed the beach managers in-depth, mostly asking open-ended questions about factors impacting fishing operations. Keith stated that an in-depth interview was selected since it was both rich in contextual information and profound incomprehension (2006). It was also deemed perfect because the researcher was looking for personal interpretations and perspectives of beach managers. The researcher made personal notes during the interview process with the beach managers as a method for later coding and analysis.

The interviews focused on factors such as species and monthly fish landings from 2001 to 2011, which is the most current ten years period. Given that the beach managers provided information based on their recall, this period was appropriate. The study also employed interviews with beach managers to learn more about the impact of climatic and non-climatic elements on fishing activities. Beach managers who have been fishing for the past ten years regularly between 2001 and 2011 were deemed significant informants for the study. The researcher spoke with beach managers who stated that they had been active in fishing activities in the area for at least ten years before 2011 .

Table 2. Selected beaches and sampling grid (GOK 2008)

\begin{tabular}{lcccc}
\hline $\begin{array}{c}\text { Beach name } \\
(\mathbf{n = 8 )}\end{array}$ & $\begin{array}{c}\text { Beach } \\
\text { manager }\end{array}$ & $\begin{array}{c}\text { Registered } \\
\text { fishermen }\end{array}$ & $\begin{array}{c}\text { No. of } \\
\text { fishermen }\end{array}$ & $\begin{array}{c}\text { Sample size } \\
(\mathbf{\%})\end{array}$ \\
\hline Kihanja & 1 & 55 & 14 & 25.45 \\
Othany & 1 & 98 & 25 & 25.51 \\
Usoma & 1 & 76 & 19 & 25.00 \\
Rare & 1 & 201 & 50 & 24.87 \\
Usare & 1 & 141 & 35 & 24.82 \\
Dunga & 1 & 393 & 98 & 24.94 \\
Kusa & 1 & 230 & 58 & 25.22 \\
Koguta & 1 & 220 & 55 & 25.00 \\
Total & 8 & 1,414 & 354 & 25.04 \\
\hline
\end{tabular}




\section{Document analysis guide}

According to Kombo (2006), Document analysis is a social research method and a vital research instrument in and of itself and an essential component of most triangulation methods. Documentary research utilizes outside sources, such as documents, to support the viewpoint or thesis of academic work. Documentary research frequently entails some or all of the following steps: conceptualizing, using, and evaluating documents. In documentary research, the records are either quantitatively or qualitatively analyzed (or both). All researchers who utilize documents in their research must consider the specific issues surrounding types of documents and their ability to use them as credible sources of evidence in the social world.

Document Analysis Guide was utilized to obtain secondary data from the Kenya Marine and Fisheries Department, Kisumu County; the Kisumu Meteorological Station in the current study, which used two types of datasets, namely climatic and fisheries data. The researchers used documented data on monthly fish landings for the past 10 years from 2001-to 2011. This was available from the Kenya Marine and Fisheries Department in Kisumu and visited the beaches. By evaluating information provided by the Kenya Marine Fisheries Department, data on the number of fish collected on the beaches was established. The weight of fish or fish landings (in kilograms) in Kisumu County beaches were utilized as the fishing data. Monthly data on the volume and fish species was available from 2005 to 2011, while annual statistics were available for regions from 2001 to 2011. This data was obtained from a document analysis guide. Secondary data on meteorological factors such as rainfall and temperature, on the other hand, was acquired from Kisumu's Meteorological Department to establish the trend of these variables during the same period (2001 to 2011). The data were collected daily. Rainfall and temperature data were reliable. However, the data about wind speed and direction provided by Kenya Meteorological Department was limited.

\section{Data analysis}

Data were analyzed using both quantitative and qualitative methods. Before being grouped into the numerous topics of the research objectives, the qualitative data was edited, paraphrased, and summarized for easier understanding. The researcher presented the data in direct verbatim or narrative form. This helped to complement the findings from the quantitative data. The researcher employed descriptive and inferential statistics to analyze the quantitative data. Tables, charts, and graphs were utilized to display the findings, while descriptive statistics such as mean, frequencies, and percentages were employed to summarize the data. To form inferences and draw conclusions, inferential statistics were used. Pearson's product-moment of correlation, which was used to analyze the association between yearly rainfall and fish abundance, was the most common inferential statistic utilized. All significance tests were performed with a significance level of 0.05 . Because of its versatility and ability to manipulate vast amounts of data, the Statistical Package for Social Sciences (SPSS) version 20 was used to analyze the data.

\section{Data management and ethical considerations}

All respondents were adequately informed about the purpose of the study and the consequences of participating. On the other hand, the researcher kept all respondents' identities private, and the information gathered from them was used for no other purpose than the research. All of the sources used in this study were credited correctly.

\section{RESULTS AND DISCUSSION}

\section{Demographic characteristics of the respondents}

Age, degree of education, marital status, other sources of income, experience in fishing activities, and average fishing income were among the demographic features of the respondents discussed. These factors were significant in the study because they influenced fishing activity.

\section{Age of respondents}

Table 3 shows that $90.6 \%$ of the respondents (fishermen) were over the age of 20 , compared to $9.4 \%$ between 15 and 19. The majority of the fishers were adults, indicating that they were legal age to engage in fishing activities. Class 8 and Form 4 leavers who had recently taken up fishing as a source of income were identified as those between 15 and 19 .

\section{The educational level of respondents}

Table 4 shows that the majority of the sampled fishermen $(69.46 \%)$ had completed primary school, $23.15 \%$ had completed secondary school, and the remainder, $7.39 \%$, had only completed nursery school. This indicates that primary education was the highest degree of education for the majority of the sampled fishers. There was no respondent among the sampled fishers who had received any college education. This is attributable to the fact that fishing operations do not necessitate any specific knowledge; most fishers are apprentice graduates.

\section{Marital status of respondents}

The study's findings suggest that $70.1 \%$ of the sampled fisherman were married, $24 \%$ were single, and $4 \%$ were widowers/widowers, as shown in Figure 3. The majority of the fisherman interviewed were married, according to the findings. Because of the lower levels of education (Table 4), many young people begin their family lives soon after dropping out of school. This was most likely the reason why, despite their youth, the majority of the fisherman polled had already married. 


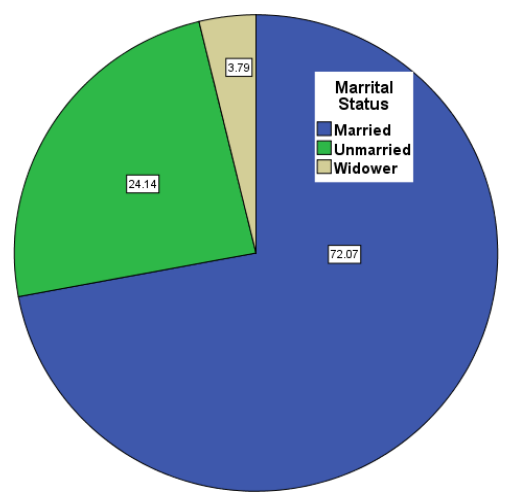

Figure 3. Marital status of the fishermen

Table 3. Age of respondents

\begin{tabular}{lcc}
\hline $\begin{array}{l}\text { Age category } \\
\text { (years) }\end{array}$ & $\begin{array}{c}\text { Frequency } \\
(\mathbf{n = 2 9 8})\end{array}$ & $\begin{array}{c}\text { Percentage } \\
(\mathbf{\%})\end{array}$ \\
\hline $15-19$ & 28 & 9.40 \\
$20-25$ & 69 & 23.15 \\
$26-30$ & 63 & 21.14 \\
$31+$ & 138 & 46.31 \\
Total & 298 & 100.00 \\
\hline
\end{tabular}

Table 4. Educational levels of the respondents.

\begin{tabular}{lcc}
\hline Level of education & $\begin{array}{c}\text { Frequency } \\
(\mathbf{n = 2 9 8})\end{array}$ & Percentage (\%) \\
\hline College Level & 0 & 0.0 \\
Secondary & 69 & 23.15 \\
Primary & 207 & 69.46 \\
Nursery & 22 & 7.39 \\
Total & 298 & 100.00 \\
\hline
\end{tabular}

Table 5. Availability of other sources of income among the fishers.

\begin{tabular}{lcc}
\hline $\begin{array}{c}\text { Availability of other } \\
\text { sources of income }\end{array}$ & $\begin{array}{c}\text { Frequency } \\
(\mathbf{n = 2 9 8 )}\end{array}$ & $\begin{array}{c}\text { Percentage } \\
(\boldsymbol{\%})\end{array}$ \\
\hline Yes & 96 & 32.21 \\
No & 202 & 67.79 \\
Total & 298 & 100.00 \\
\hline
\end{tabular}

Table 6. Other sources of income among the fishers.

\begin{tabular}{lcc}
\hline Another source of income & $\begin{array}{c}\text { Frequency } \\
(\mathbf{n = 9 6 )}\end{array}$ & $\begin{array}{c}\text { Percentage } \\
(\mathbf{\%})\end{array}$ \\
\hline Business & 59 & 61.46 \\
Farming & 29 & 30.21 \\
Pension & 8 & 8.33 \\
Total & 96 & 100.00 \\
\hline
\end{tabular}

\section{Other sources of income}

Only $32.2 \%$ of fishers were involved in other incomegenerating activities, as shown in Table 5, while the remaining $67.8 \%$ relied only on fishing for their livelihood. These findings suggested that fishing was the sole source of income for the majority of the fishers. As a result, the fishing activities in Lake Victoria, Kisumu County, were economically significant to the residents. Those fishermen who answered they had other sources of income were asked to specify what type of source they got their money from, and the results are shown in Table 6.

Table 6 illustrates that the fishers earned money through various activities other than fishing. $61.5 \%$ of fishers had other sources of income, $30.2 \%$ were farmers, and $8.3 \%$ were retirees who relied on pensions. This could indicate that the revenue generated by the sampled fishers' fishing operations was insufficient, necessitating the need to augment it with other sources of income. These findings were supported by results from the interviews, which revealed that weighted fish captured at the eight beaches only ranged from $1000 \mathrm{~kg}$ to $6,000 \mathrm{~kg}$ each month on average. According to the beach manager, only one of the beaches had a monthly weighted fish catch of $45,000 \mathrm{~kg}$. In terms of monetary worth, these proved insufficient to adequately support families whose breadwinners were only engaged in fishing operations, as indicated in Table 8.

\section{Experience of fishing among fishermen}

The fishers were questioned about their experience in the fishing industry. Given that fishing abilities are acquired informally through apprenticeship, it was thought that their responses would allow the study to measure the level of fishing knowledge among the fishers. The fishers' responses are listed in Table 7.

Table 7 revealed that most of the sampled fishers $(57.1 \%)$ had more than ten years of fishing experience. As a result, the majority of the fisherman polled had sufficient fishing experience. This data was judged to be relevant since it revealed that the responses provided by the sampled fishermen were reliable, based on their extensive experience fishing in Lake Victoria. This information is consistent with that gathered from the interviews with the beach managers, which revealed that seven of the eight managers had served in the same role at the same beach for periods ranging from one to seven years.

\section{The average income per month from fishing}

Having established the existence of other sources of income among the fishers, the study sought to determine how much income the fishers realized on average from their fishing activities per month. The researcher explored the fishers' income from fishing activities to gather responses to this question. The average monthly income per fisherman is summarized in Table 8 .

Table 8 shows that $38.6 \%$ of the sampled fishers had a monthly average income of Kshs.3,000 or less, while $38.6 \%$ had a monthly average of Kshs.3,001-Kshs.7,000. As a result, it is evident that the bulk of the sampled fisherman had a very low average income, with only roughly $22 \%$ having an average income of more than Kshs.7,000. These statistics explain why most fishers may need to supplement their income from fishing with other sources of income such as farming and business. One of the reasons the fishers had no other sources of income was a lack of capital to diversify into other income-generating enterprises. 
Table 7. Experience among the fishermen

\begin{tabular}{lcc}
\hline \multicolumn{1}{c}{ Fishing Experience } & $\begin{array}{c}\text { Frequency } \\
(\mathbf{n = 2 9 8})\end{array}$ & Percentage $(\boldsymbol{\%})$ \\
\hline 10 years \& below & 128 & 42.95 \\
11-15years & 58 & 19.46 \\
16+ years & 112 & 37.59 \\
Total & 298 & 100.00 \\
\hline
\end{tabular}

Table 8. Fishers' average income from fishing per month.

\begin{tabular}{lcc}
\hline $\begin{array}{c}\text { Average income } \\
\text { (Ksh.) }\end{array}$ & $\begin{array}{c}\text { Frequency } \\
(\mathbf{n = 2 9 8})\end{array}$ & $\begin{array}{c}\text { Percentage } \\
(\mathbf{\%})\end{array}$ \\
\hline $1-1,000$ & 8 & 2.68 \\
$1,001-2,000$ & 70 & 23.49 \\
$2,001-3,000$ & 37 & 12.42 \\
$3,001-4,000$ & 0 & 0.00 \\
$4,001-5,000$ & 57 & 19.13 \\
$5,001-6,000$ & 0 & 0.00 \\
6,001-7,000 & 58 & 19.46 \\
Above 7,000 & 68 & 22.82 \\
Total & 298 & 100.00 \\
\hline
\end{tabular}

Table 9. Average annual weight and value of fish catch from Lake Victoria, Kisumu County.

\begin{tabular}{lccc}
\hline \multicolumn{1}{c}{ Type of Fish } & $\begin{array}{c}\text { Weight } \\
(\mathbf{k g})\end{array}$ & $\begin{array}{c}\text { Value } \\
\text { (Ksh.) }\end{array}$ & $\begin{array}{c}\text { Value } \\
\text { per kg } \\
\text { (Ksh) }\end{array}$ \\
\hline Oreochromis spp. & 268,361 & $21,222,638$ & 79.10 \\
Lates niloticus & 359,223 & $29,732,933$ & 82.80 \\
Rastrinoebola argentea & 408,427 & $14,984,296$ & 36.70 \\
Clarias gariepinus & 135,140 & $7,957,835$ & 58.90 \\
Protopterus spp. & 57,809 & $3,205,514$ & 55.50 \\
Others & 68,981 & $2,465,803$ & 35.80 \\
Total & $1,297,941$ & $79,569,019$ & \\
\hline Sol &
\end{tabular}

Source: Compiled from Kisumu County Fisheries Department (2014)

\section{Type and amounts of fish caught in Lake Victoria}

The researcher conducted a documentary examination of the records of fish caught by species and the monetary worth annually to determine the kind and number of fish caught. Rastrineobola argentea, Lates niloticus, Clarias gariepinus, Oreochromis spp., Protopterus spp., Haplochromine spp., Schilbe spp., Labeo spp., and Synodontis spp. were among the principal fish species found in Lake Victoria, according to the findings. The most common fish captured were Oreochromis spp., Rastrineobola argentea, Clarias gariepinus, Protopterus spp., and Lates niloticus. Table 9 shows that the weight and value of the five most prevalent varieties of fish taken in Lake Victoria vary significantly. The weight of the fish caught was recorded in kilograms, and the value was calculated using the market price paid at the landing beach.

Table 9 shows the annual average volume and value of several types of fish collected from 2001 to 2011, as calculated from Kisumu County Fisheries Department records.

Annually, 1,297,941 kg of fish worth Ksh.79,569,019 were taken in Kisumu County's Lake Victoria. Lates niloticus brought in the most money (Kshs. 29,732,933) annually, followed by Oreochromis spp. at Ksh.21,222,638 and Rastrinoebola argentea, which had the most significant weight (almost 4 tonnes annually) and generated Ksh.14,984,296 on an annual basis. This investigation shows that, although having the largest catchweight, Rastrinoebola argentea has a poor value compared to Oreochromis spp. and Lates niloticus.

\section{Relationship between climatic elements and fishing activities}

One of the research problems addressed in this study was the association between climatic conditions and fishing activity in Kisumu County's Lake Victoria. Winds (both strong and mild), rainfall, and dry spells were among the meteorological conditions evaluated in this context. The responders responded by describing how each climatic aspect had affected their Lake Victoria fishing operations.

\section{Effects of winds on fishing activities in Lake Victoria}

During the discussions with the beach managers, it became clear that the winds that blow over Lake Victoria are diverse. The fisherman divided the winds into two categories: strong and mild. However, the study's findings demonstrated that mild or strong wind could influence fish behavior and, ultimately, fishing operations. According to the study, winds affected fishing in Lake Victoria in diverse ways (Table 10). Mild breeze has been proven to have a favorable impact on fish catch because it stimulates fish movement in the water, allowing fishers to catch fish that would otherwise hide deep in the lake bed. According to the study's findings, mild winds block the penetration of the sun's rays into the water, creating a favorable environment for fish growth and development. Winds also freshen the water by mixing it, providing a healthy environment for fish to flourish.

Table 10 summarizes the fishers' responses to the impact of wind on their fishing activities in Lake Victoria. The study discovered that moderate wind speeds were adequate for boat movement on the water and that mild winds generated a more favorable atmosphere for fishing activities than severe winds. Strong winds were shown to have a greater negative impact; for example, $30.9 \%$ of fishers claimed they couldn't sail on the lake effectively during strong winds, and $3.7 \%$ said strong winds hindered the fish passage because water weed stuck to the water surface. Fishers identified other difficulties in response to strong winds, including boat accidents in the lake $(44.30 \%)$. Losses of bait and already caught fish were reported by $11.4 \%$ and $9.7 \%$ of the fishers, respectively. $43.3 \%$ of fishers stated they slowed down their movement during fishing in the water during mild winds, while $56.7 \%$ claimed they saw greater fish productivity during mild winds. 
Table 10. Effect of winds on fishing activities.

\begin{tabular}{lcc}
\hline \multicolumn{1}{c}{ Effect of strong winds } & $\begin{array}{c}\text { Frequency } \\
(\mathbf{n = 2 9 8})\end{array}$ & $\begin{array}{c}\text { Percentage } \\
(\%)\end{array}$ \\
\hline $\begin{array}{l}\text { Hinder the fishers from sailing in } \\
\text { their boats }\end{array}$ & 92 & 30.87 \\
Sticking water weeds blocks the way & 11 & 3.69 \\
of fish & & \\
Accidents to the fishermen & 132 & 44.30 \\
Loss of fish already caught & 29 & 9.73 \\
Loss of baits used by the fishermen & 34 & 11.41 \\
$\quad$ Total & 298 & 100.00 \\
Effect of mild winds & Freq. $(\mathrm{n}=298)$ & $\begin{array}{c}\text { Perc. }(\%) \\
\text { Slow down movement of fishermen }\end{array}$ \\
Increased fish production & 129 & 43.29 \\
$\quad$ Total & 299 & 56.71 \\
& & 100.00 \\
\hline
\end{tabular}

The beach managers have noticed that little fish rise to the water's surface as the wind strength lowers. As a result of these findings, mild winds had a greater positive impact on fishing activities than severe winds, negatively affecting fishing activities. As a component of the climate, this means that wind impacts fishing activities. These findings supported the postulation of Ogutu-Ohwayo that wind speed and direction, among other things, can drastically alter fish population abundance, dispersion, and availability. The association between wind and fishing activity was also validated in oral interviews with beach managers, which agreed with the fishers' comments. One of the beach managers at one of the beaches in the research area, for example, said: "Mild winds, such as Kus and Matarae, are known for bringing a lot of rain and fish. This promotes fishing by facilitating fish feeding, boat movement, and mixing the water in the lake. There is very little fishing when these two breezes do not blow. Strong winds such as Nyamranga and Nyamaseno, on the other hand, can be extremely dangerous and can blow at any time. Such hazardous winds reduce fishing activity by causing fish to hide in the mud, breaking boats, and potentially killing fisherman in accidents."

\section{Effects of rain on fishing activities}

Table 11 shows that most fishermen $(58.4 \%)$ said that fish were swept away by floods after heavy rains, whereas $5 \%$ said that fish died due to the severe downpours. However, $35.2 \%$ of respondents stated their fish harvest increased as the rain increased, while $1.4 \%$ of fishers said they became ill after extreme downpours. According to these data, heavy rains had various consequences on fishing in Lake Victoria. Brander (2007) concluded that rainfall event frequency and intensity were expected to significantly impact future fisheries productivity in both inland and marine systems. Although Brander (2007) did not specify how the frequency and intensity of rainfall affected fish productivity, this study found that fish catch was higher for several types of fish when there were significant rains. This was proven through an interview with beach managers, who ascribed the increase of Lates niloticus and Protopterus spp. to heavy rains.
The hypothesis that climate factors have no substantial influence on fishing activities in Lake Victoria, Kisumu County, was evaluated using bivariate Pearson moment correlation to establish the association between climatic elements and fishing activities in Lake Victoria, Kisumu County.

A Pearson correlation analysis was undertaken after preliminary investigations to establish that the assumptions of normality, linearity, and homoscedasticity were not violated. Table 12 summarizes the findings of a bivariate Pearson moment correlation between the amount of rain and the number of fish caught by a fisherman in Lake Victoria, Kisumu County. The correlation data demonstrated a relationship between heavy rains and the amounts of fish caught by fishers; there is a direct relationship between rainfall intensity and the amounts of fish caught (Table 12). The findings of a correlation analysis of rainfall data and fish capture records revealed that rainfall had a significant positive relationship with fish catches for several types of fish (Table 12). This suggested that rainfall affected fish catches in Lake Victoria, Kisumu County, even though the effect varied by fish type. While Tilapia $(\mathrm{r}=.260$; sig. level =.033), Lates niloticus $(\mathrm{r}=.130$; sig. level =.022), and Protopterus spp. $(\mathrm{r}=.184)$ showed a positive connection with rainfall; the amount of rainfall negatively correlated with Rastrinoebola argentea (-.786; sig. level=.051) and Claras gariepinus ( $\mathrm{r}=-.012$; sig. level $=.014)$. Overall, the findings demonstrated a weak but positive correlation ( $\mathrm{r}=.079$, sig. level.025) between the rainfall and the total amount of fish caught. Based on these findings, it was concluded that, while rainfall intensity had both a negative and positive impact on fish caught in the lake, it was clear that, in general, the higher the amount of rain, the more fish caught.

Table 11. Effect of heavy rains on fishing activities

\begin{tabular}{lcc}
\hline Effects of heavy rains & $\begin{array}{c}\text { Frequency } \\
(\mathbf{n = 2 9 8})\end{array}$ & $\begin{array}{c}\text { Percentage } \\
(\mathbf{\%})\end{array}$ \\
\hline Floods carry fish & 174 & 58.38 \\
Death of fish & 15 & 5.03 \\
Higher fish catch & 105 & 35.24 \\
Illness to fishermen & 4 & 1.35 \\
Total & 298 & 100.00 \\
\hline
\end{tabular}

Table 12. Correlation between fish catch and annual rainfall amount

\begin{tabular}{lcc}
\hline \multicolumn{1}{c}{ Type of fish } & \multicolumn{2}{c}{ Amount of rainfall } \\
\hline Oreochromis spp. & $\begin{array}{c}\text { Pearson } \\
\text { correlation }\end{array}$ & $\begin{array}{c}\text { Sig. level } \\
\text { (2-tailed) }\end{array}$ \\
Lates niloticus & .260 & .033 \\
Rastrinoebola argentea & .130 & .022 \\
Clarias gariepinus & -.786 & .051 \\
Protopterus spp. & -.012 & .014 \\
Overall & .184 & .002 \\
\hline
\end{tabular}

Note: *. Correlation is significant at the 0.05 level (2-tailed). 
These connections can be explained by considering how rainfall re-distributes nutrients for fish in the lake, which impacts the fish's spawning time. Because Lake Victoria is an inland lake, our findings support Brander's (2007) claim that precipitation and water management changes impact inland fisheries. Heavy rains send silt and other debris into the lake, reducing the capture of Nile perch and Tilapia, but increasing the catch of indigenous fish such as lungfish and catfish, designed to survive without oxygen for short periods. This finding is similar to that of Barthem and Goulding (1997). They discovered that catfish are adapted to live in the muddy water because they have a highly developed organ called the Weberian apparatus that connects the inner ear, swim bladder, and lateral line system, making them sound specialists capable of preying in muddy areas.

As demonstrated in Table 12, the statistical nonsignificance $(\mathrm{P} . \mathrm{V}=.051)$ was only recorded in the occurrence of Rastrinoebola argentea, which showed a negative correlation ( $\mathrm{r}=-.786)$ with rain. However, it was also noticed in the conversation with the fishers that with severe rains, the fish catch normally increases. As a result, rainfall as a climatic component altered Lake Victoria's fishing activities.

\section{Effects of a dry spell on fishing activities in Lake Victoria}

According to Table 13, 86.6\% of fishers indicated a fish shortage during the dry spell; just $6.4 \%$ thought the fish catch rose during the dry period, and $7.04 \%$ said there was no change in fish caught. As a result, most of the fishers interviewed reported a fish shortage during the dry spell. These findings echoed those of Mackenzie and Koster (2004), who found that variations in water temperature impacted fish harvest in the Baltic and the Black Sea. In North Carolina, they discovered that sprat catches were substantially higher than usual during warm years than cold years (Baltic Sea).

The researcher interviewed the beach managers to remark on the effect of the dry spell on fishing activities in Lake Victoria to corroborate this finding with their perspectives, and this is what one of them said: "During a dry period, the fish catch decreases because the water along the coast is warmer, which inhibits fish occurrence. As a result, most fish migrate to the middle of the lake in search of cooler water. Because most fish species do not like warm water, the fish catch can drop to as low as $200 \mathrm{~kg}$ per day and $1,800 \mathrm{~kg}$ per month during this time. This means that beach managers confirmed that fish catch decreases during dry spells, a phenomenon they blame for rising water temperatures along the coast, which discourages fish occurrence; most fish swim deeper into the lake in search of calmer waters beneath. They claim that this drastically reduces the volume of fish caught. As a result of these data, it can be concluded that dry spells have a negative impact on fishing activities in Lake Victoria, Kisumu County.

\section{Relationship between non-climatic factors and fishing activities in Lake Victoria}

The effects of non-climatic factors were crucial to the researcher in this study because they would find other factors that they believed affected fishing activities in Lake Victoria. Non-climatic factors such as fishing gear theft, a lack of good technical skills, bad infrastructure, and a lack of sufficient finance, among others, were thought to have a substantial impact on Lake Victoria's fishing activities. The fishers' were asked to indicate factors that they believed influenced fishing activities in Lake Victoria; they were not limited to choosing just one factor but were free to choose all of the factors they believed influenced fishing activities. As a result, their responses in Table 14 had numerous responses to the identified factors. The proportion of respondents who identified each item as a factor affecting fishing activity in Lake Victoria is shown in the percentage column. Water hyacinth, lack of engine boats, theft of fishing gear in the water, lack of refrigeration facilities, limited capital, insecurity, predation, overfishing, and poor marketing, all of which led to overexploitation by individual businessmen, were some of the significant challenges faced by the fishers who took part in the study. Among all the non-climatic factors that the fishermen mentioned as affecting their fishing activities in Lake Victoria, water hyacinth stood out as the most influential factor, with a frequency percentage occurrence of $64.8 \%$.

This is supported by Keteregga and Sterner's (2007) findings that water hyacinth was a significant threat to fishing and directly impacted fishing activity. According to the fishers, the hyacinth infestation in Lake Victoria has a lot of social and economic consequences for fishing. It has been discovered that its rapid development causes physical obstruction of streams and water abstraction units, obstructing water transit and obstructing fishing activities. It also produces a high number of long-lived seeds that can survive for an extended period, as well as a weed population that swiftly doubles. The weed creates a permanent floating vegetation cover over the highly productive open water surface, affecting the food web and ecological diversity. It was also discovered that the plant provided ideal breeding grounds for mosquitoes and other insects, leading to an increase in illness outbreaks among fishers. Furthermore, the weed suffocates aquatic life by deoxygenating the water, depletes nutrients for juvenile fish in sheltered bays, and disrupts local subsistence fishing by limiting access to beaches.

Table 13. Effect of dry spell on fishing activities

\begin{tabular}{lcc}
\hline \multicolumn{1}{c}{ Effect of dry spell } & $\begin{array}{c}\text { Frequency } \\
(\mathbf{n = 2 9 8})\end{array}$ & $\begin{array}{c}\text { Percentage } \\
(\boldsymbol{\%})\end{array}$ \\
\hline Shortage of fish & 258 & 86.58 \\
Increase in fish catch & 19 & 6.38 \\
No change in fish catch & 21 & 7.04 \\
Total & 298 & 100.00 \\
\hline
\end{tabular}


On the other hand, the presence of hyacinth was found to be more favorable to fish growth and development in a study by Njiru et al. (2012). Most fishers agree that the hyacinth mats should be left where they do not disrupt other economic activities. Whatever the case may be, it is critical to track the impact of water hyacinth on fisheries activities over time to understand better the linkages between fish population dynamics and hyacinth regrowth. According to an analysis of the fishers' responses, $36.9 \%$ of them believed that the presence of the Nile perch (Lates niloticus) in Lake Victoria had endangered other small fish. The aggressive predatory nature of the Nile perch wreaked havoc on the species composition of Lake Victoria. The Lake used to have a diverse range of fish species; however, once the Nile perch was introduced in the 1950s, this diversity was significantly decreased. This study's findings were similar to Ogari (2001) and Muthama et al. (2007). They found that Nile perch, as an invasive fish species, had a significant impact on the fish species composition of Lake Victoria. The presence of Nile perch, on the other hand, has contributed both negatively and positively to the Lake Victoria fisheries, according to this study. Improved export revenues, an increased supply of desirable protein food, increased fish productivity, and increased employment and earnings for fishers were all beneficial outcomes. According to the fishers, fishing activities in Lake Victoria have also been hampered by a lack of capital.

As shown in Table 14, security issues were another major factor affecting fishing activities in Kisumu County's Lake Victoria, with piracy $(21.5 \%)$ and theft $(28.5 \%)$ among the severe difficulties that needed to be addressed. The theft took place on two levels, including already caught fish and fishing equipment. The fishers would band together and sell fish in the lake before landing on the beaches, effectively cutting into the profits of the boat owners. Although piracy was not prevalent in Kisumu County's Lake Victoria, the study found a severe security issue that resulted in the loss of machinery, fish, and occasionally lives when fishers were attacked while on the lake. Another aspect that led to the exploitation of the fishers by middlemen was poor marketing $(8.7 \%)$. It was discovered that middlemen would acquire fish from a fisher for a low price and then sell it for a higher price. Due to a lack of refrigeration, fish had to be sold as soon as caught, or they would decay. As a result, the fishers were willing to accept highly cheap rates because they were at the whim of the middlemen.

Finally, a lack of technical knowledge and relevant skills has been identified as a serious issue affecting the fishing business. Lack of technical expertise was cited by more than half of the respondents $(56.7 \%)$ as a problem influencing fishing activities in Lake Victoria. The majority of fishers relied only on apprenticeship to learn the necessary skills. This was insufficient since the trainee fisherman would be taught by equally inexperienced instructors who, like the trainee fishers, relied solely on experience and lacked the necessary knowledge and abilities to back them up-mitigation measures to cope with the influence of climate and non-climatic factors on fishing activities in Lake Victoria.

Table 15 summarizes the procedures that fishermen in the studied area claimed they had put in place to deal with climatic and non-climatic factors influencing fishing activities in Lake Victoria. Table 15 shows that $24.2 \%$ of the surveyed fishers believed that increased security is one way to address safety concerns about fishing in Lake Victoria. It's worth noting that some of the respondents mentioned theft and piracy as some of the problems that affect their fishing activities. As a result, increased security may be able to help.

Table 15 shows that $66.1 \%$ of fishers believe that infrastructure development is better to address transportation problems they face while fishing. This indicates that most respondents believed a good road network around the beaches was necessary to increase lake fishing. The development of a strong road system could help with transportation within the fishing zone and open up the region to allow fishers access to necessary services such as health centers, schools for their children, and other social amenities. Because fish is a perishable product, better facilities such as electricity and large-scale refrigeration are required if fishers avoid significant losses and exploitation by middlemen. One approach to ensure this happened was to start road and electricity projects on these beaches; fostering a general improvement in the road network and electricity was crucial in fishing activity.

Table 14. Other factors affecting fishing activities in Lake Victoria

\begin{tabular}{lcc}
\hline $\begin{array}{c}\text { Another factor affecting } \\
\text { fishing }\end{array}$ & $\begin{array}{c}\text { Frequency } \\
(\mathbf{n = ~ 2 9 8 )}\end{array}$ & $\begin{array}{c}\text { Percentage } \\
(\mathbf{\%})\end{array}$ \\
\hline Water hyacinth & 193 & 64.8 \\
Pirates & 64 & 21.5 \\
Capital & 145 & 48.7 \\
Theft & 85 & 28.5 \\
Threat by other fish & 110 & 36.9 \\
Technical knowhow & 169 & 56.7 \\
Aquatic animals & 52 & 17.4 \\
Poor infrastructure & 76 & 25.5 \\
Poor marketing & 26 & 8.7 \\
\hline
\end{tabular}

Table 15. Mitigation measures on factors affecting fishing in Lake Victoria, Kenya

\begin{tabular}{lcc}
\hline \multicolumn{1}{c}{ Mitigation measures } & $\begin{array}{c}\text { Frequency } \\
(\mathbf{n = 2 9 8})\end{array}$ & $\begin{array}{c}\text { Percentage } \\
(\mathbf{\%})\end{array}$ \\
\hline Security & 72 & 24.2 \\
Development of infrastructure & 197 & 66.1 \\
Business & 22 & 7.4 \\
Farming & 7 & 2.3 \\
Total & 298 & 100.00 \\
\hline
\end{tabular}


In conclusion, according to the study findings, factors like mild winds, high rainfall, and cool temperatures all positively influenced fishing activities in Lake Victoria by resulting in high fish catches, as these created a conducive environment for fish to thrive. In contrast, other climatic factors like strong winds and high temperatures resulted in low fish catches, resulting in losses and reduced revenue. Non-climatic elements were shown to have a detrimental impact on fishing activity, according to the findings of the study. Fishing activities in the Lake were hampered by a lack of capital, theft among fishers, and water hyacinth. Although most of these non-climatic factors were outside the fishers' control because they were matters requiring county government intervention, the study revealed that the fishers had put in place some steps to help them avoid detrimental effects on their fishing business. They took deliberate action to strengthen security, clear the water hyacinth, restrict fishing locally, develop storage facilities, seek markets, and organize small fish cooperative societies to supply capital for better fishing equipment.

\section{REFERENCES}

Aloo-Obudho PA. 2010. Contribution of the Fisheries Sector towards Food Security and Poverty Alleviation in Kenya. Tropentag, Nederlands.

Andjelic MM. 1999. Strategy for Support Sustainable Development in the Lake Victoria Region, SIDA, Stockholm, Sweden.

Barthem L, Goulding M. 1997. The Catfish Connection. Columbia University Press, New York.

Brander KM. 2007. Present Fisheries Production Trends and Threats: International Council for the Exploration of the Sea, Copenhagen, Denmark.

Cohen L, Manion L. 2006. Research Methods in Education. Routledge Publisher, New York. DOI: 10.4324/9780203029053.

Daskalov H. 1999. Relating fish recruitment to stock and physical environment in the Black Sea using generalized additive models. Fish Res 41 (1): 1-23. DOI: 10.1016/S0165-7836(99)00006-5.

DEA [Department of Environmental Affairs]. 2013. Long-Term Adaptation Scenarios Flagship Research Programme (LTAS) for South Africa. Climate Change Implications for Marine Fisheries in South Africa, Pretoria, South Africa.
Gichuki J, Omondi R, Boera P, Tom O, SaidMatano TA, Jembe T, Ofulla A. 2012. Water Hyacinth Dynamics and Succession in the Nyanza Gulf of Lake Victoria (East Africa): Implications for Water Quality and Biodiversity conservation. Sci World J 2012: 106429. DOI: $10.1100 / 2012 / 106429$.

Gislason H. 1999. Single and Multispecies reference points for Baltic fish stocks. ICES (International Council for Exploration of the Sea). J Mar Sci 56 (5): 71-583. DOI: 0.1006/jmsc. 1999.0492

Glantz MH. 2007. Climate Variability; Climate Change and Fisheries. Cambridge University Press, UK.

ICES. 2001. Report of the Baltic Fisheries Assessment Working Group. ICES CM 2001 ACFM; 18, International Council for Exploration of the Sea. Copenhagen, Denmark.

Idrisi N, Luthy S, Capo TR, Serafy JE. 2003. In captivity, behavior oxygen consumption and survival of stressed juvenile sailfish (Istiophorus platypterus). Mar Freshw Behav Physiol 36 (1): 51-57. DOI: $10.1080 / 1023624021000054299$.

Kateregga E, Sterner T. 2007. Indicators for an invasive species: Water hyacinths in Lake Victoria. Ecol Indic 7 (2): 362-370. DOI: 10.1016/j.ecolind.2006.02.008.

Keith FP. 2006. Developing Effective Research Proposal SAGE Publications, London.

Kimathi AN, Ibuathu CN, Guyo HS. 2013. Factors Affecting Profitability of Fish Farming Under Economic Stimulus Programme in Tigania East District, Meru County. IOSR J Business Manag 15 (3): 25-36 DOI: $10.9790 / 487 \mathrm{X}-1532536$

Kombo DK, Tromp DLA. 2006. Proposal and Thesis Writing; An Introduction. Paulines Publications, Copenhagen, Denmark.

Kusemiju K. 1991. Fishes, Man and the Aquatic Environment, University of Lagos Press, Nigeria.

Lejju JB. 2012. The influence of climate change and human-induced environmental degradation on Lake Victoria, OSSREA Publication, Nigeria.

Mackenzie BR, Koster FW. 2004. Fish production and climate sprat in the Baltic Sea. Ecol Soc Amer 85 (3): 784-794. DOI: 10.1890/02-0780

Muthama NJ, Owino J, Ndetto EL. 2007. The influence of weather on fish catches in Lake Victoria in Tanzania. J Kenya Meteorol Soc 1 (1): 55 66.

Ogari J. 2001. Impact of exotic fish species and invasive waterweeds such as the water hyacinth on Lake Victoria fisheries. LVEMP Conference, Kisumu, Kenya.

Rasmussen E. 1985. El Nino and variations in climate. Am Sci 73 (2): $168-177$.

Sixtus K. 2011. Lake Victoria, Experience and Lessons Learned Brief. Dar'essalaam University, Tanzania.

Stram DL, Evans DCK. 2009. Fishery Management responses to climate change in the North Pacific. ICES J Mar Sci 66 (7): 1633-16339. DOI: 10.1093 icesjms/fsp138.

WCS. 2011. Lungfish (Protopterus aethiopicus) in Lake Victoria (East Africa), East African Wildlife Society. African J Ecol 40 (1): 42-52. 